\title{
Metallothionein 2 and Heat Shock Protein 72 Protect Allolobophora chlorotica from Cadmium But Not Nickel or Copper Exposure: Body Malformation and Coelomocyte Functioning
}

\author{
Joanna Homa ${ }^{1}$ - Stephen R. Stürzenbaum ${ }^{2}$ - Elzbieta Kolaczkowska ${ }^{1}$
}

Received: 7 December 2015/Accepted: 18 March 2016/Published online: 2 April 2016

(c) The Author(s) 2016. This article is published with open access at Springerlink.com

\begin{abstract}
Earthworms serve as good indicators of heavy metal contamination due to their innate sensitivity towards soil pollution. However, to date, not many studies have focused on endogeic earthworms, such as the omnipresent Allolobophora chlorotica. The current study was designed to verify whether this earthworm could serve as a novel distinctively susceptible species for environmental contamination studies. We show that the dermal exposure to $\mathrm{Cu}, \mathrm{Ni}$, and $\mathrm{Cd}$ affected the mortality and morphology of $A$. chlorotica, and the number and functioning of coelomocytes. These features particularly were pronounced in animals treated with $\mathrm{Ni}$ and $\mathrm{Cu}$ and interestingly to a lesser extend with $\mathrm{Cd}$. In contrast, $\mathrm{Cd}$ induced a strong expression of metallothioneins (MT-2) and heat shock proteins (HSP72). The presence of MT-2 was detected not only in coelomocytes but also in the intestine, blood vessels, and epidermis. In conclusion, Allolobophora chlorotica coelomocytes are adopted to respond differentially to various heavy metals, generating powerful response towards potentially most dangerous exogenous non-essential elements.
\end{abstract}

Earthworms are one of the most important macroinvertebrates, because their presence influences soil properties and availability of resources to their inhabitants (Kooch and

Joanna Homa

joanna.homa@uj.edu.pl

1 Department of Evolutionary Immunology, Institute of Zoology, Jagiellonian University, Gronostajowa 9, 30-387 Krakow, Poland

2 Analytical and Environmental Sciences Division, Faculty of Life Sciences \& Medicine, King's College London, London, UK
Jalilvand 2008). Likewise, when the well-being of earthworms is impaired, for example due to soil contamination, with pesticides or heavy metals, important soil functions can be compromised (Calisi et al. 2014; Giska et al. 2014; Leitão et al. 2014). For this reason, earthworms are environmental sentinels and biological indicators of soil quality and pollution. The earthworm coelomic cavity contains coelomocytes, immunocompetent cells classified as amoebocytes, and eleocytes/chloragocytes (Engelmann et al. 2004; Kurek et al. 2007). Whilst amoebocytes can recognize foreign materials (e.g., pathogens) and are involved in phagocytosis and encapsulation (Cossarizza et al. 1996; Engelmann et al. 2004; Kalaç et al. 2002), eleocytes store endogenous materials such as glycogen and lipids (Roots and Johnston 1966), as well as exogenous compounds, such as pigments or metals (Prentø 1979, Fisher and Molnár 1992). Chloragocytes also have been associated with the immune defense, because they secrete bacteriostatic compounds (Valembois et al. 1992) and are involved in encapsulation and in the formation of brown bodies (Cooper and Stein 1981; Field et al. 2004; Valembois et al. 1992, 1994). Moreover, all coelomocytes are involved in heavy metal trafficking within the earthworm body (Homa et al. 2007; Honeycutt et al. 1995).

An exposure to heavy metals results in the upregulation of numerous genes resulting in the expression of proteins involved in the detoxification of metals and/or repair of lesions. In particular, the expression of metallothioneins (MTs) and heat shock proteins (HSPs) increase in the presence of heavy metals (Calisi et al. 2009; Homa et al. 2005; Kammenga et al. 2000). Indeed, metallothioneins play a crucial role in the metabolism, transport, homeostasis, and detoxification of essential and nonessential metals (Calisi et al. 2009, 2014; Dallinger 1996; Roesijadi 1996). There are two MT isoforms, M1 participates more 
in physiological activities, whereas MT2 binds nonessential metals, such as cadmium (Morgan et al. 2004).

Heavy metals also can induce the expression of cytoprotective heat shock proteins (HSPs) functioning as molecular chaperons controlling protein-protein interactions and preventing redundant protein aggregation (Kiang and Tsokos 1998; Luan et al. 2010; Moseley 2000; Nadeau et al. 2001; Piano et al. 2004). In particular, the family of 70-kDa heat shock proteins (HSP-70) represents one of the most abundant stress proteins, and among them Hsp72 protects cells against cellular stress (cytoprotection), also in earthworms (Nadeau et al. 2001). Any stressor, including heavy metals, affects the immune system equilibrium disturbing not only the production of immune-related proteins (Nadeau et al. 2001) or the cells cycle (Shackelford et al. 1999) but also more general processes, such as worm behavior, reproduction, offspring viability, ageing, and population level effects (Homa et al. 2003; Liess 2002). Whilst the epigeic Eisenia fetida is widely used in acute toxicity tests (Maboeta et al. 2004), the endogeic Allobophora chlorotica is less well studied. However, unlike E. fetida, which is restricted to territories rich in decaying organic material (compost), A. chlorotica can be found in a wide range of habitats, including forests, meadows, agriculture areas, and city gardens (Sizmur et al. 2011), and therefore feeds on and thus stays in constant contact with soil. This renders A. chlorotica an excellent candidate for comparative ecotoxicological studies on different ecosystems. Indeed, A. chlorotica are sensitive to heavy metal $(\mathrm{Zn}>\mathrm{Pb}>\mathrm{Cd}>\mathrm{Cu}$ ) polluted soil (Homa et al. 2003), and their coelomic fluid contain an abundance of amoebocytes and eleocytes (Kurek et al. 2007).

The goal of the current study was to establish whether endogeic earthworm species, such as A. chlorotica, are suitable biomonitors of metal contamination. Additionally, we aimed to identify immunological parameters that would be modulated differentially by various distinct heavy metals. Therefore, the current study challenged $A$. chlorotica to a range of cadmium, copper, and nickel doses. Together with $\mathrm{Hg}$ and $\mathrm{Pb}, \mathrm{Cd}$ is one of the big three heavy metal poisons and is not known for any essential biological function, whereas $\mathrm{Ni}$ and $\mathrm{Cu}$ are among heavy metals essential for healthy plant and animal growth (Wuana and Okieimen 2011). The mortality rate and malformation of the worm body were monitored, changes in eleocyte composition, lysosomal membrane stability (via the neutral red test) were assessed, and the expression of MT-2 and HSP72 were quantified. Not only has the study revealed that $A$. chlorotica is a suitable model for studies on heavy metal impact on immunity, but it showed differential modes of the response. In fact, the impact on body malformation and earthworm mortality was weakest in response to potentially most dangerous (nonessential) cadmium and the strongest mortality towards copper, which in low doses is essential for normal functioning.

\section{Materials and Methods}

\section{Animals and Exposure Condition}

Adult (clitellate) Allolobophora chlototica (Sav.) were field collected (unpolluted experimental garden at the Institute of Zoology, Jagiellonian University, Krakow, Poland) and maintained in controlled laboratory conditions $\left(16 \pm 1{ }^{\circ} \mathrm{C}\right.$; 12:12 LD) in unpolluted soil samples for at least 2 weeks for acclimatization. The experiments were conducted according to the standard filter paper contact method (Homa et al. 2005; OECD 1984). Briefly, after $3 \mathrm{~h}$ on moist filter paper, each worm $(0.31 \pm 0.075 \mathrm{~g}$ body weight, $n=3-10)$ was washed, dried, and placed individually in $50-\mathrm{ml}$ vials filled with filter paper that was soaked with either tap water (control) or a heavy metal chloride solution $(11,22,44,66,88$, or $176 \mu \mathrm{g} / \mathrm{ml}$, which corresponds to $0.33,0.66,1.32,1.98,2.64,5.28 \mu \mathrm{g} / \mathrm{cm}^{2}$ of heavy metals). In addition, control animals were kept in natural soil. Doses of heavy metals were selected based on previous publications (Homa et al. 2005, 2010; Plytycz et al. 2011) and adopted to cover a range of several dilutions not to overlook effects of any dose. The highest doses were chosen based on pilot studies in which their impact on earthworm mortality was monitored. A. chlorotica turned out to be very sensitive to $\mathrm{Cu}$ as three highest doses $(66,88$, and $176 \mu \mathrm{g} / \mathrm{ml}$ ) were fatal for the worms. For this reason, we were only able to obtained results when applying up to $44 \mu \mathrm{g} / \mathrm{ml}$ of $\mathrm{Cu}$, and we only show mortality (100\%) for the higher dose $(66 \mu \mathrm{g} / \mathrm{ml})$ as an example.

\section{Harvesting of Coelomocytes}

After 3 days exposure to the heavy metals, earthworms were inspected to identify morphological abnormalities and photographed. Subsequently, earthworms were placed individually in Petri dishes containing phosphate buffered saline (PBS, Gibco) and stimulated for 1 min with a $4.5-\mathrm{V}$ electric current to expel coelomic fluid containing coelomocytes through the dorsal pores, according to the procedure described previously (Homa et al. 2005; Roch 1979). Extruded coelomocytes were used for tests described below.

\section{Flow Cytometric Measurement and Analyses}

To determine the cell composition of the coelomic fluid, the coelomic fluid samples were analysed with a FACScalibur flow cytometer (BD Biosciences). During analytical experiments, 10,000 threshold events per worm sample were collected and 
analysed for forward scatter (FSC) (for cell size) and sideward scatter (SSC) (cell complexity) properties. Fluorescence FL1$\mathrm{H}$ (emission $530 \mathrm{~nm}$; excitation $488 \mathrm{~nm}$ ) was recorded to detect autofluorescent eleocytes (Homa et al. 2010).

\section{Neutral Red Uptake}

To determine neutral red (NR) uptake by cells, the extruded coelomocytes were incubated for $10 \mathrm{~min}$ in the presence of the NR solution (Sigma-Aldrich; in PBS) at a final concentration of $40 \mu \mathrm{g} / \mathrm{ml}$ as described previously (Weeks and Svendsen 1996). Then, the cells were analysed by means of a FACScalibur flow cytometer (Plytycz et al. 2007). By producing density plots of FL2-H (neutral redderived fluorescence) versus side scatter SSC (indicating cell complexity/granularity) allowed the proportion of neutral red accumulating cells to the $\mathrm{NE}^{-}$cells to be quantified. The resulting data were analyzed with the WinMDI 2.9 software (Joe Trotter, http://facs.scripps.edu).

\section{Immunohistochemistry Detection of Metallothionein (MT-2)}

Coelomocytes from individuals earthworms were used for cytospin preparations as described previously (Homa et al. 2005). For cross-section preparations, segments posterior to the clitellum were fixed for $4 \mathrm{~h}$ in $2 \%$ paraformaldehyde dissolved in PBS and then washed for $1 \mathrm{~h}$ in $12 \%$ saccharose, and overnight in $25 \%$ saccharose (both dissolved in PBS) (Baumann 1997). Subsequently, tissues were frozen in liquid nitrogen and sectioned $(7 \mu \mathrm{m})$ on a cryostat (Shandon OT, Astmoor, Runcorn, Cheshire, UK), fixed with solution of $70 \%$ cold ethanol, and stored as frozen samples $\left(-20^{\circ} \mathrm{C}\right)$ until further analyses. Next, the cross-section preparations were subjected to immunoperoxidase staining with rabbit polyclonal antibody raised against metallothionein 2 (wMT-2) from Lumbricus rubellus (Hoeckner et al. 2015; Morgan et al. 2004; Stürzenbaum et al. 2001) diluted 1:500 and a secondary goat anti-rabbit $\mathrm{IgG}_{1}$ antibody conjugated with horseradish peroxidase (Sigma-Aldrich Co., St. Louis, MO; dilution 1:1000). The reaction was developed using DAB $\left(3,3^{\prime}\right.$-diaminobenzidine) HRP substrate (Sigma-Aldrich) and counter stained with hematoxylin for cell nuclei visualization (Stamar, Poland). The sections were imaged and photographed with a Jenamed-2 microscope (Carl Zeiss Jena) fitted with Nikon digital camera (Coolpix 4500).

\section{Immuno-Blot Detection of Heat Shock Protein HSP72 and MT-2}

To examine expression of stress proteins, dot-blot assays were performed in a 96-well plate format using a Bio-dot microfiltration manifold (Bio-Rad, Hercules, CA). Lysates of coelomocytes were prepared according to the manufacturer's protocols (Roche Applied Diagnostic GmbH, Mannheim, Germany) and as described previously by Homa et al. (2005). First, protease inhibitor cocktail PMSF (Roche) was used to prepare coelomocyte extracts. The amount of protein was determined by the BCA method (Sigma Aldrich), and samples were adjusted to an equal concentration. Subsequently, $50 \mu \mathrm{l}$ of samples $(35 \mu \mathrm{g}$ of protein) was added to each well of the microfiltration apparatus and the blotting was performed according to a standard (Bio-Rad). Then, the membranes were blocked for 45 min at $37{ }^{\circ} \mathrm{C}$ in a blocking buffer containing $5 \%$ nonfat milk solution (Gostyń) dissolved in TBS (20 mM Tris$\mathrm{HCl}, 500 \mathrm{mM} \mathrm{NaCl}, \mathrm{pH}$ 7.5). Next, the membranes were treated with monoclonal anti-HSP72 biotin conjugated antibody (Stressgen, San Diego, CA) diluted 1:4000 or rabbit polyclonal antibodies raised against MT-2 from Lumbricus rubellus (1:1000 in TTBS (TBS with $0.05 \%$ Tween 20) (Homa et al. 2005; Morgan et al. 2004) containing $1 \%$ non-fat milk, and incubated overnight at $4{ }^{\circ} \mathrm{C}$. For MT-2 staining, horseradish peroxidase conjugated secondary goat anti-rabbit $\operatorname{IgG}_{1}$ antibody (Sigma-Aldrich) diluted 1:10,000 was used. Next, the membranes were washed at room temperature by continuous shaking in TTBS. The HSP72 was immunodetected with Streptavidin-Alkaline Phosphatase (SAv-AKP) (BD Pharmingen, San Diego, CA) after $30 \mathrm{~min}$ incubation at room temperature. Then, the reaction was developed by addition of BCIP/NBT substrates (Bio-Rad). The MT-2 reaction was developed using DAB (3,3'-diaminobenzidine) HRP substrate (Sigma-Aldrich). The membranes were air-dried and a densitometric analysis of protein dots was performed using of the UVISoft-UVIMap program (UVItec, Ltd.).

\section{Data Analysis and Statistics}

Results are expressed as means \pm standard errors (SE). Significant differences between means were evaluated using one-way ANOVA, and a post hoc Tukey (Statistica, StatSoft) test with the level of significance was established at $p<0.05$.

\section{Results}

\section{Viability, Morphological Abnormality, Composition and Number of Coelomocytes}

Following a 3-day exposure to heavy metals, significant mortality was observed in earthworms exposed already to $44 \mu \mathrm{g} / \mathrm{ml}$ for $\mathrm{Cu}$ (100\% mortality) and $88 \mu \mathrm{g} / \mathrm{ml}$ for $\mathrm{Ni}$ ( $18 \%$; Table 1). In contrast, first fatalities due to $\mathrm{Cd}$ 
Table 1 Allolobophora chlorotica mortality and coelomocyte composition in response to heavy metals

\begin{tabular}{llllll}
\hline & $\mu \mathrm{g} / \mathrm{ml}$ & Mortality $(\%)$ & $\mathrm{C}\left(\times 10^{6}\right)$ & $\mathrm{A}\left(\times 10^{6}\right)$ & $\mathrm{E}\left(\times 10^{6}\right)$ \\
\hline Soil & 0 & 0 & $4.62 \pm 0.39^{\mathrm{a}}$ & $1.99 \pm 0.25^{\mathrm{a}}$ & $2.63 \pm 0.30^{\mathrm{a}}$ \\
$\mathrm{H} \mathrm{H}_{2} \mathrm{O}$ & 0 & 0 & $4.65 \pm 0.41^{\mathrm{a}}$ & $2.19 \pm 0.35^{\mathrm{a}}$ & $2.46 \pm 0.25^{\mathrm{a}}$ \\
$\mathrm{Ni}$ & 22 & 0 & $1.20 \pm 0.55^{\mathrm{b}}$ & $0.88 \pm 0.61^{\mathrm{a}}$ & $0.32 \pm 0.12^{\mathrm{b}}$ \\
& 44 & 5.9 & $2.68 \pm 0.48^{\mathrm{b}}$ & $1.12 \pm 0.17^{\mathrm{a}}$ & $1.56 \pm 0.39^{\mathrm{b}}$ \\
& 66 & 12.5 & $1.08 \pm 0.31^{\mathrm{b}}$ & $0.79 \pm 0.33^{\mathrm{ab}}$ & $0.28 \pm 0.07^{\mathrm{b}}$ \\
& 88 & 17.6 & $1.93 \pm 0.64^{\mathrm{b}}$ & $1.10 \pm 0.35^{\mathrm{a}}$ & $0.82 \pm 0.29^{\mathrm{b}}$ \\
$\mathrm{Cu}$ & 176 & 66.7 & $\mathrm{nt}$ & $\mathrm{nt}$ & $\mathrm{nt}$ \\
& 11 & 0 & $1.64 \pm 0.50^{\mathrm{b}}$ & $0.79 \pm 0.24^{\mathrm{b}}$ & $0.85 \pm 0.28^{\mathrm{b}}$ \\
& 22 & 7.7 & $2.28 \pm 0.44^{\mathrm{b}}$ & $1.26 \pm 0.23^{\mathrm{ab}}$ & $1.02 \pm 0.24^{\mathrm{b}}$ \\
& 44 & 83.3 & $1.04(\mathrm{NS})$ & $0.50(\mathrm{NS})$ & $0.54(\mathrm{NS})$ \\
$\mathrm{Cd}$ & 66 & 100 & $\mathrm{nt}$ & $\mathrm{nt}$ & $\mathrm{nt}$ \\
& 22 & 0 & $3.98 \pm 0.64^{\mathrm{a}}$ & $2.63 \pm 0.53^{\mathrm{a}}$ & $1.35 \pm 0.21^{\mathrm{ab}}$ \\
& 44 & 0 & $4.03 \pm 0.56^{\mathrm{a}}$ & $2.13 \pm 0.35^{\mathrm{a}}$ & $1.89 \pm 0.25^{\mathrm{ab}}$ \\
& 66 & 0 & $4.30 \pm 0.43^{\mathrm{a}}$ & $2.33 \pm 0.48^{\mathrm{a}}$ & $1.98 \pm 0.52^{\mathrm{ab}}$ \\
& 88 & 0 & $3.54 \pm 0.53^{\mathrm{a}}$ & $1.63 \pm 0.22^{\mathrm{a}}$ & $1.92 \pm 0.41^{\mathrm{ab}}$ \\
& 176 & 30 & $3.30 \pm 0.75^{\mathrm{a}}$ & $1.88 \pm 0.69^{\mathrm{a}}$ & $1.42 \pm 0.41^{\mathrm{b}}$ \\
\hline
\end{tabular}

Control earthworms were maintained either in soil or on water $\left(\mathrm{H}_{2} \mathrm{O}\right)$-soaked filter paper. Experimental animals were exposed to different concentrations of $\mathrm{Ni}, \mathrm{Cu}$, and $\mathrm{Cd}$ for 3 days. Amebocytes (A), eleocytes (E), and total coelomocyte counts (C) were determined using a hemocytometer, mean \pm SE, $p<0.05$

Different letters (a vs. b) indicate that mean values are statistically significantly different from soil controls $N S$ no statistical analyses was performed due to high mortality, $n t$ not tested exposure were detected only at the highest concentration tested $(176 \mu \mathrm{g} / \mathrm{ml})$. Distinct morphological changes were detected in animals exposed to heavy metals (Fig. 1), which were in particular profound in earthworms exposed to following doses of $\mathrm{Cu}(44 \mu \mathrm{g} / \mathrm{ml})$ and $\mathrm{Ni}(88 \mu \mathrm{g} / \mathrm{ml})$ and the highest dose of $\mathrm{Cd}(176 \mu \mathrm{g} / \mathrm{ml}$; Fig. 1). The abnormalities typically included the blistering of the body wall (Figs. 1e-i), bloody lesions (Fig. 1d), vesicles (Fig. 1h), disruption of metameric segmentation (Fig. 1j), abnormal swelling at clitellar region (Fig. 1e), and a body fragmentation at the posterior region (Fig. 11).

The number and composition of coelomocytes was very similar in worms maintained in control (unpolluted) soil or exposed for 3 days to $\mathrm{H}_{2} \mathrm{O}$ soaked filter paper. In contrast, exposure to $\mathrm{Cu}$ and $\mathrm{Ni}$ significantly decreased the number of coelomocytes, especially eleocytes. Although no statistically significant changes were observed in Cd exposed worms, there was a tendency towards altered composition of amebocytes but not eleocytes (Table 1). Altogether, concentrations of the tested heavy metals required to kill half of the individuals in given experimental groups were as follows: $\mathrm{LC} 50 \mathrm{Ni}=176$, $\mathrm{LC} 50 \mathrm{Cu}=44$, and $\mathrm{LC} 50 \mathrm{Cd}=176 \mu \mathrm{g} / \mathrm{ml}$.

\section{Flow Cytometric Measurements and Neutral Red Uptake}

Compared with unexposed control earthworms, the percentage of eleocytes decreased upon exposure to any of the three metals (Figs. 2a left, b). More than $90 \%$ of cells took up the neutral red dye within the 10-min exposure period (Fig. 2a upper right); however, coelomocytes derived from animals exposed to heavy metals were marked by an impaired uptake of NR (Fig. 2a lower right, representative data). If NR was not added, there was not any signal in FL2-H channel (not shown). Although the ratio of NRnegative $\left(\mathrm{NR}^{-}\right)$cells was higher in $\mathrm{Ni}$ and $\mathrm{Cu}$ exposed samples (compared with the control group, data not shown), the difference was less obvious when adjusted to cell numbers (Fig. 2b, c). However, the exposure to $\mathrm{Cd}$ significantly decreased the uptake of NR (more $\mathrm{NR}^{-}$cells) either when expressed as ratio of $\mathrm{NR}^{+} / \mathrm{NR}^{-}$(Fig. 2a lower right) or plotted against coelomocyte numbers (Fig. 2c).

\section{Immunodetection of MT-2}

Immunohistochemical analyses revealed that the expression of MT-2 was modulated in coelomocytes (Fig. 3a, b) and in body compartments (Fig. $4 \mathrm{a}, \mathrm{b}$ ) of $\mathrm{Ni}, \mathrm{Cu}$, and $\mathrm{Cd}$ exposed earthworms. While base line levels of MT-2 were detected in coelomocytes derived from control earthworms, the expression increased in the cells extracted from heavy metal exposed worms (Fig. 3a, representative images from the $\mathrm{Cd}$ exposed animals). To confirm expression of MT-2 in other cell compartments, cell lysates were prepared and the expression was evaluated by Dot-blotting (Fig. 3b). The signal was significantly elevated in animals exposed to 

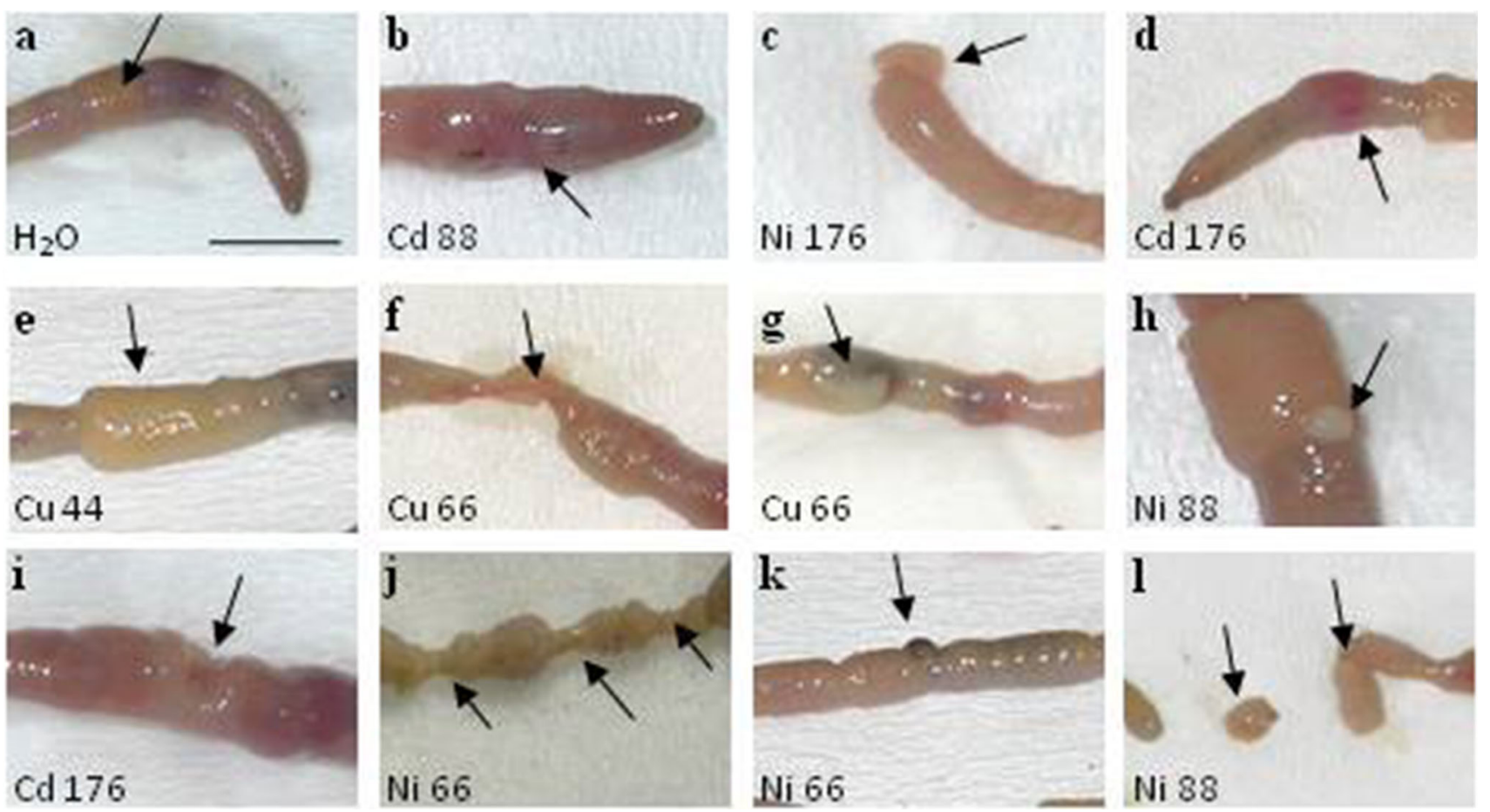

Fig. 1 Effect of heavy metals $(\mathrm{Ni}, \mathrm{Cu}$, and $\mathrm{Cd})$ on the earthworm Allolobophora chlorotica morphology following 3-day exposure on filter paper. Examples of abnormal morphology of the earthworms exposed to different concentrations of the heavy metals $(66-176 \mu \mathrm{g} /$ $\mathrm{ml}$ ). Control worms were maintained in $\mathrm{H}_{2} \mathrm{O}$-soaked filter paper. Note intact morphology with visible clitellum (a) scale bar $1 \mathrm{~cm}$. Exposing earthworms to filter paper soaked with a heavy metal solution resulted

$\mathrm{Ni}, \mathrm{Cu}$, and in particular $\mathrm{Cd}$. Interestingly, MT-2 levels also increased in various other tissues and vital organs (Fig. 4a, b), including the chloragogenous tissue, the typhlosolar fold and in intestinal epithelial cells adjacent to the gut lumen (Fig. 4a). Elevated MT-2 expression also was evident in the body wall (the entry point of metals), the nephridia (implicated in the removal of metabolites), and blood vessels (involved with the circulation and distribution of nutrients/contaminants; Fig. 4b). It should be noted at this stage that the weak signal was present in animals exposed to $\mathrm{H}_{2} \mathrm{O}$ via the filter paper test but not in the worms maintained in soil (Fig. 4a).

\section{Immunoblot-Detection of Heat Shock Proteins HSP72}

The expression of heat shock proteins HSP72 in coelomocytes lysates was upregulated in animals exposed to any of the three heavy metals. Although high doses of heavy metals significantly induced the expression of HSP72, the most pronounced increase was observed at the lower exposure range (Ni 44/66, Cu 11/22, and $\mathrm{Cd} 44 \mu \mathrm{g} / \mathrm{ml}$; Fig. 5). The HSP72 signal in the $44 \mu \mathrm{g} / \mathrm{ml} \mathrm{Cu}$ sample was
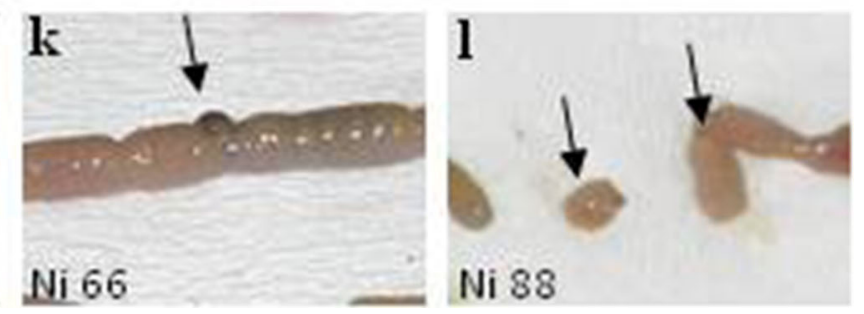

in different malformations and swelling of the anterior part (b), abnormal shape of the posterior end (c), bloody lesions (d), abnormal swelling at clitella region (e). Abnormalities typically included blistering of the body wall (f-i), disruption of metameric segmentation $(\mathbf{j})$, rupture in body wall $(\mathbf{k})$, and body fragmentation at the posterior region (I). Letters and numbers in each panel denote the metal and corresponding concentration (in $\mu \mathrm{g} / \mathrm{ml}$ )

lower than the control group; however, data were derived from a single individual, namely the sole survivor following the 3-day treatment regime (Fig. 5).

\section{Discussion}

Earthworms commonly inhabit soils and litter layers, promote soil biodiversity, soil fertility, and soil health and thus are important indicators of environmental transformations and pollution (Palm et al. 2013). Although earthworm species can populate different niches, they form part of an ecological guild that is not universal to any environment (Paoletti 1999). Indeed, earthworms are classified into three ecological life types: anecics (e.g., Eisenia fetida, Dendrobaena veneta), endogeics (e.g., Allolobophora chlorotica), and epigeics (e.g., Lumbricus rubellus). The classification takes into account the structure of their burrows, but most importantly, the three ecological groups differ in their importance in soil functioning (Palm et al. 2013). Accordingly, they might respond to soil contamination in distinct ways, which will influence their utility as bioindicators. 
Fig. 2 Flow cytometric analysis of coelomocytes derived from earthworms (Allolobophora chlorotica) maintained in soil or exposed to filter paper soaked either with $\mathrm{H}_{2} \mathrm{O}$ (control) or heavy metals: $\mathrm{Ni}, \mathrm{Cu}, \mathrm{Cd}(11-176 \mu \mathrm{g} / \mathrm{ml})$. a Representative density plots of coelomocytes derived from control worms $(\mathrm{Cd} 0)$ and worms exposed to cadmium $(\mathrm{Cd}$ 66, $66 \mu \mathrm{g} / \mathrm{ml})$. Cells were incubated in vitro for $10 \mathrm{~min}$ in the presence or absence of Neutral Red dye (NR). Without NR: plots of FL1-H autofluorescence versus cell complexity (SSC-H). Gates set on the density plot indicate two populations of coelomocytes: amoebocytes (A), and eleocytes (E) (left panel). With NR: FL2$\mathrm{H}$ fluorescence versus cell complexity (SSC-H). Gates set on the density plot indicate two populations of coelomocytes: cells that did not absorb NR

$\left(\mathrm{NR}^{-}\right)$, and the cell that took in $\mathrm{NR}\left(\mathrm{NR}^{+}\right)$. b Ratio of autofluorescent eleocytes (E \%) and $\mathbf{c}$ ratio of coelomocytes that did not absorb NR $\left(\mathrm{NR}^{-} \%\right)$.

Mean \pm SE, $n=3-10$,

$p<0.05$. Different letters ( $a$ vs. $b$ ) indicate that mean values are statistically significantly different from controls (a)

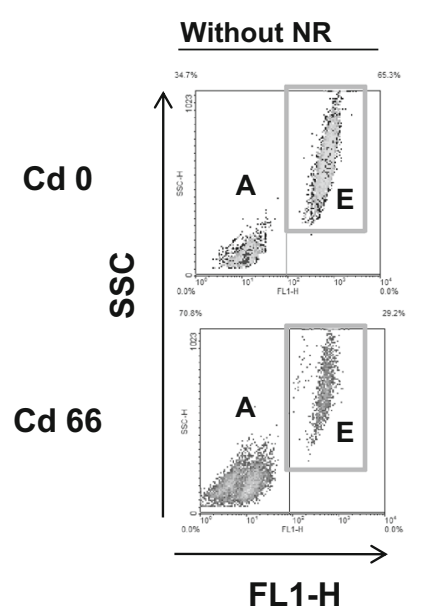

(b)

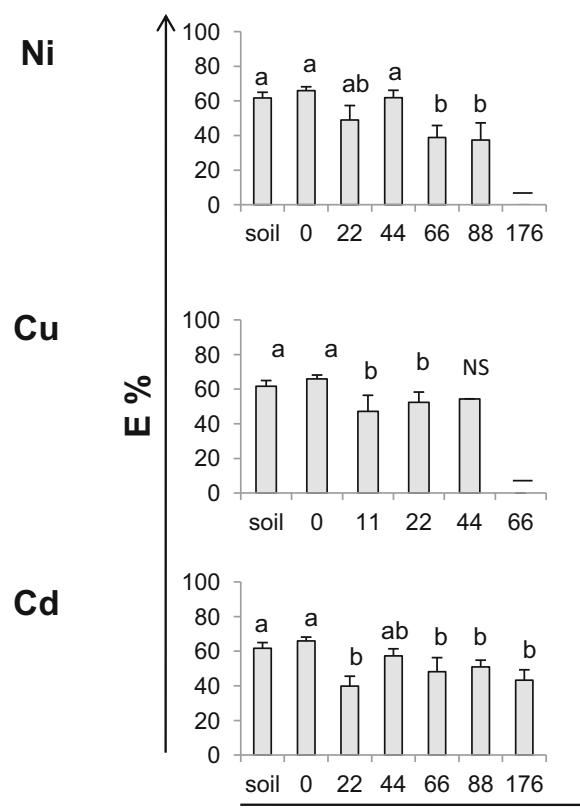

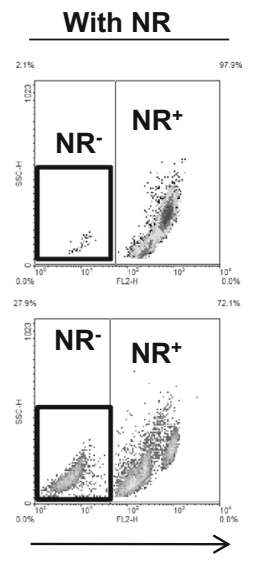

FL2-H (c)

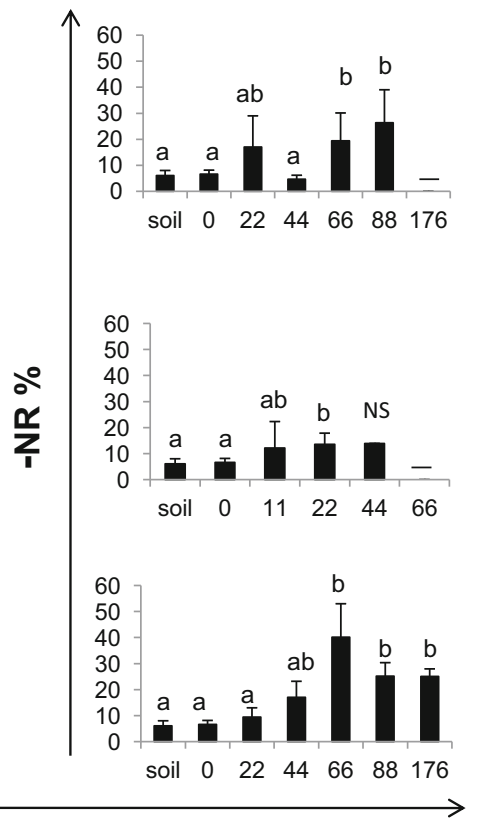

$(\mu \mathrm{g} / \mathrm{ml})$

Whilst epigeic and anecic earthworms are routinely studied, few have focused on endogeic species. This study aims to redress this shortfall by evaluating the sensitivity of the endogeic Allolobophora chlorotica to heavy metals. In detail, several potential biomarkers of stress/intoxication were measured, including viability and changes in morphology of animals, numbers and activity of coelomocytes, induction of heat shock proteins (HSP72), and metallothioneins (MT-2). The results demonstrate that exposure to copper, nickel, and cadmium chlorides induced significant changes in all of the studied biomarkers in A. chlorotica. However, the degree of induced changes differed between the metals, with $\mathrm{Ni}$ and $\mathrm{Cu}$ inducing highest mortality and most profound morphological changes, and $\mathrm{Cd}$ exposure leading to the strongest expression of cytoprotective proteins. No mortality or any symptoms of morphological changes were observed in the control group $\left(\mathrm{H}_{2} \mathrm{O}\right.$ exposed $)$ throughout the experiments, whereas death and morphological abnormalities were frequently encountered in animals exposed to $\mathrm{Ni}, \mathrm{Cu}$, and $\mathrm{Cd}$. This is in line with some previous reports showing that morphological and histological endpoints can be a useful tool to evaluate pesticide and heavy metals toxicity (Venkateswara Rao et al. 2003; Venkateswara Rao and Kavitha 2004). Regarding mortality and morphological changes, our data revealed that $A$. chlorotica exhibits a differential sensitivity towards heavy metals. 

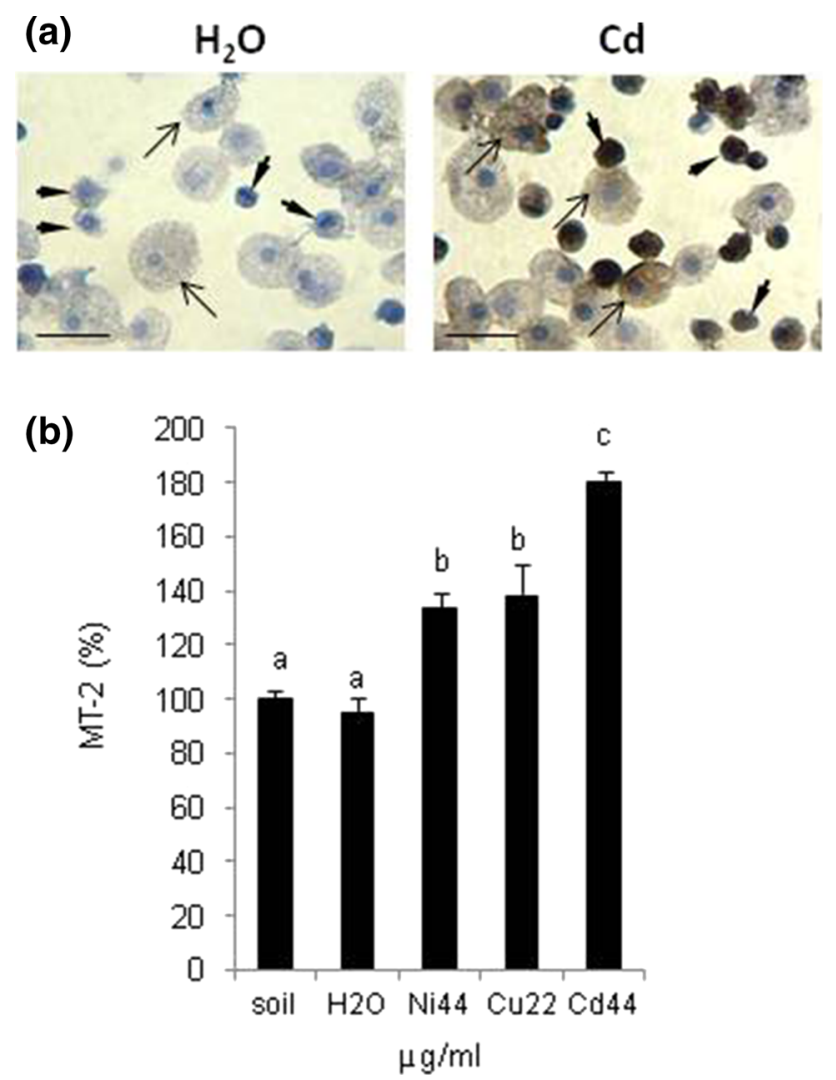

Fig. 3 Expression of metallothionein MT-2 in coelomocytes extracted from Allolobophora chlorotica exposed to heavy metals. a Representative images of immunohistochemical detection of MT-2 (brown deposit) in coelomocytes of earthworms maintained on filter paper soaked with $\mathrm{H}_{2} \mathrm{O}$ (control) or exposed to $\mathrm{Cd}(44 \mu \mathrm{g} / \mathrm{ml})$ for 3 days. Both amebocytes (arrowheads) and eleocytes (arrows) were MT-2 positive. Scale bar $25 \mu \mathrm{m}$. b Expression of MT-2 also was evaluated in all cell lysates of coelomocytes derived from animals exposed to $\mathrm{Ni}, \mathrm{Cu}$, and $\mathrm{Cd}$ at concentrations of 44,22 , and $44 \mu \mathrm{g} / \mathrm{ml}$, respectively. Mean $\pm \mathrm{SE}, n=3-10, p<0.05$. Different letters ( $a$ vs. $b)$ indicate that mean values are statistically significantly different from controls

Previous studies have reported the effect on E. fetida exposed to leaded gasoline (tetra ethyl lead), lead oxide, chlorpyrifos, and organophosphorus insecticide on the filter papers (Chakra Reddy and Venkateswara Rao 2008; Venkateswara Rao et al. 2003; Venkateswara Rao and Kavitha 2004). Pathological symptoms (many of which resembled those observed in our current study) included body swelling, curling, excessive mucus secretion, increase in clitellar region, breakage in body wall, bloody lesion, vesicles, disruption of metameric segmentation, abnormal, and fragmentations at posterior region (Venkateswara Rao et al. 2003; Venkateswara Rao and Kavitha 2004; Chakra Reddy and Venkateswara Rao 2008).

According to Scott-Fordsmand, one of the most sensitive toxicological parameter in the case of Eisenia veneta is the lysosomal membrane stability of coelomocytes (Scott-
Fordsmand et al. 1998). We used a modified test, utilizing flow cytometry, to measure neutral red (NR) accumulation in earthworm coelomocytes (Plytycz et al. 2007). NR is a vital dye that accumulates in the lysosomes of live cells. We showed that in the case of all tested heavy metals $(\mathrm{Cu}$, $\mathrm{Ni}$, and $\mathrm{Cd}$ ), a significant number of coelomocytes did not take in (accumulate) NR. An effect that was particularly pronounced in animals exposed to $\mathrm{Cd}$. Similar results were observed using coelomocytes extracted from Lumbricus terrestris (Fugère et al. 1996), E. fetida and Dendrobaena veneta (Homa et al. 2005; Olchawa et al. 2006). In addition, we explored whether protective mechanisms were activated in A. chlorotica exposed to heavy metals. In earthworms, similar to other species, exposure to heavy metals can lead to DNA damage (Fourie et al. 2007; Reinecke and Reinecke 2004), apoptosis mediated by caspases (Homa et al. 2007) and perturbations in stability of cell membrane (Asensio et al. 2007; Plytycz et al. 2007; ScottFordsmand et al. 1998; Weeks and Svendsen 1996). In response, defense mechanisms are activated, which include the expression of heat shock proteins (Homa et al. 2003, 2005), metal-binding proteins (Homa et al. 2007; Morgan et al. 2004), or glutathione transferases (Farombi et al. 2007). In the current study, the expression of HSP72 was highest at a relatively low dose of the three heavy metals. In agreement with this, coelomocytes derived from those animals exhibited an enhanced accumulation of NR and overall viability. This may suggest that HSPs protect cells from stress-induced, caspase-dependent apoptosis (Gupta et al. 2010; Parcellier et al. 2003); however, HSP72 expression was lower at higher metal concentrations. This finding aligns well with our previous study on A. chlorot$i c a$, which reported that the reduction in HSP70 and HSP72 detection was correlated to higher levels of cell death mediated by caspase 3 (Homa et al. 2007).

Metal binding metallothioneins (MTs) are important players in the metal detoxification pathway (Dallinger 1996; Morgan et al. 2004). Previous studies have demonstrated that an antibody raised against Lumbricus rubellus MT-2 (Stürzenbaum et al. 2001, 2004) is sufficiently crossreactive to allow the induction of MT-2 protein to be assessed in coelomocytes derived from $E$. fetida, D. veneta and A. chlorotica (Homa et al. 2005, 2007, 2010; Olchawa et al. 2006). Likewise, transcript quantification of MT-2 (mRNA) revealed that at least one metallothionein isoform is strongly inducible by $\mathrm{Cd}$ in A. chlorotica (Homa et al. 2010). The results presented in the current paper confirm these preliminary findings and by application of immunocytochemical and immunoblotting techniques extends the knowledge base to include valuable information surrounding the dose and time resolved expression of MT-2 in coelomocytes and other body compartments. Animals exposed to heavy metals via moist filter paper presented a 
(a)

NEGATIVE CONTROL

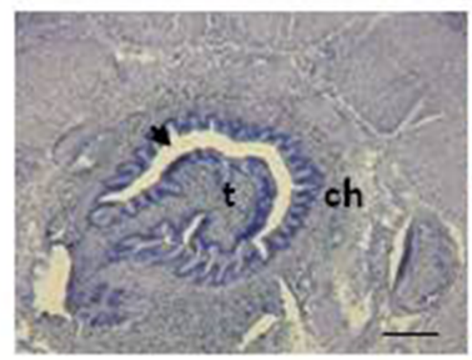

$\mathrm{Ni} 44$

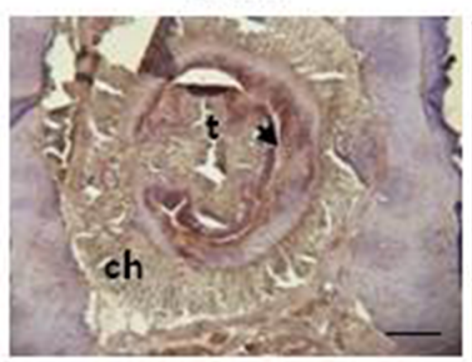

i

(b)

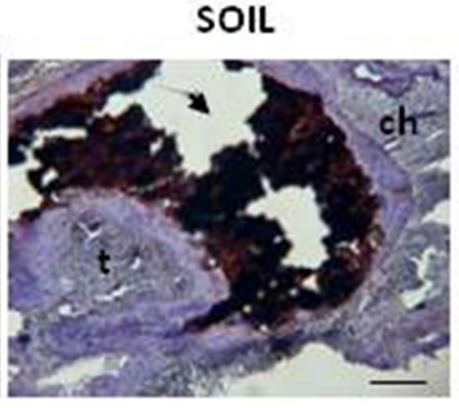

Cu 22

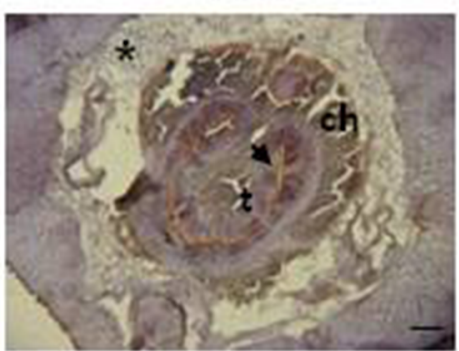

$\mathrm{H}_{2} \mathrm{O}$

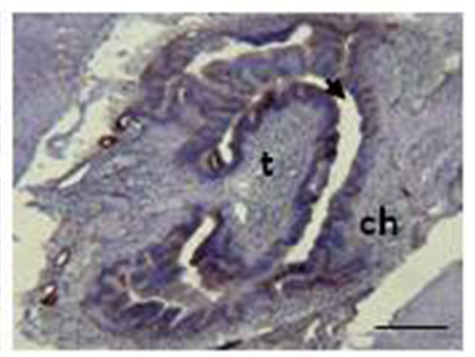

Cd 44

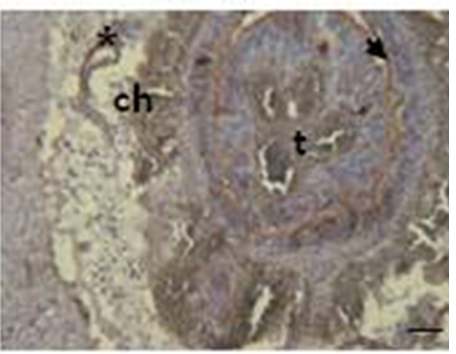

iii
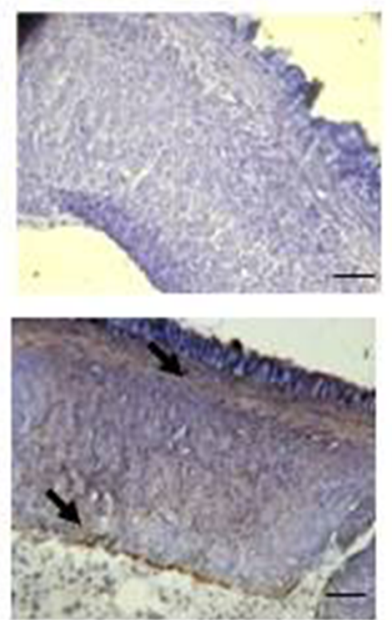

Fig. 4 Expression of metallothionein MT-2 in different body compartments of Allolobophora chlorotica. Cross-sections of earthworms were obtained from control animals maintained in soil or on filter papers soaked with $\mathrm{H}_{2} \mathrm{O}$. Experimental groups were maintained on filters soaked with heavy metals for 3 days: $\mathrm{Ni}, \mathrm{Cu}, \mathrm{Cd}(11-176 \mu \mathrm{g} /$ $\mathrm{ml}$ ). a Immunohistochemical evaluation of MT-2 expression. Negative control (lacking the primary antibody) confirmed the absence of false-positive staining; immunoperoxidase (anti-MT-2) stained as

strong MT-2 signal in the chloragogenous tissue surrounding the gut, the typhlosolar fold as well as the nephridia, blood vessels, and epithelial cells of the intestine. Noteworthy is the fact that MT-2 expression was observed in intestinal epithelial gut cells in worms exposed to filter paper soaked only in $\mathrm{H}_{2} \mathrm{O}$. Others have shown that starvation can lead to increased expression of MTs brown deposits indicates location of MT-2. $t$ typhlosole; ch chloragogen cells; asterisk free coelomocytes; arrows intestinal epithelial cells in the apical regions adjacent to the gut lumen (arrows); scale bar $100 \mu \mathrm{m}$. b Representative images showing positive staining for MT-2 after 3-day exposure to $\mathrm{Cu}(22 \mu \mathrm{g} / \mathrm{ml})$ : arrows indicate; $i$ dorsal blood vessel and chloragogen cells (ch), ii region of the nephridium, iii section through the body wall

(Hashemi et al. 2008; Sogawa et al. 2003), which might explain this finding (given that earthworms were not fed for 3 days during the filter paper exposure). Similar pattern of MT-2 expression were reported to occur in L. rubellus exposed to metals in contaminated soil (Hoeckner et al. 2015; Morgan et al. 2004). However, unlike L. rubellus, we also detected MT-2 expression in the body wall, which 


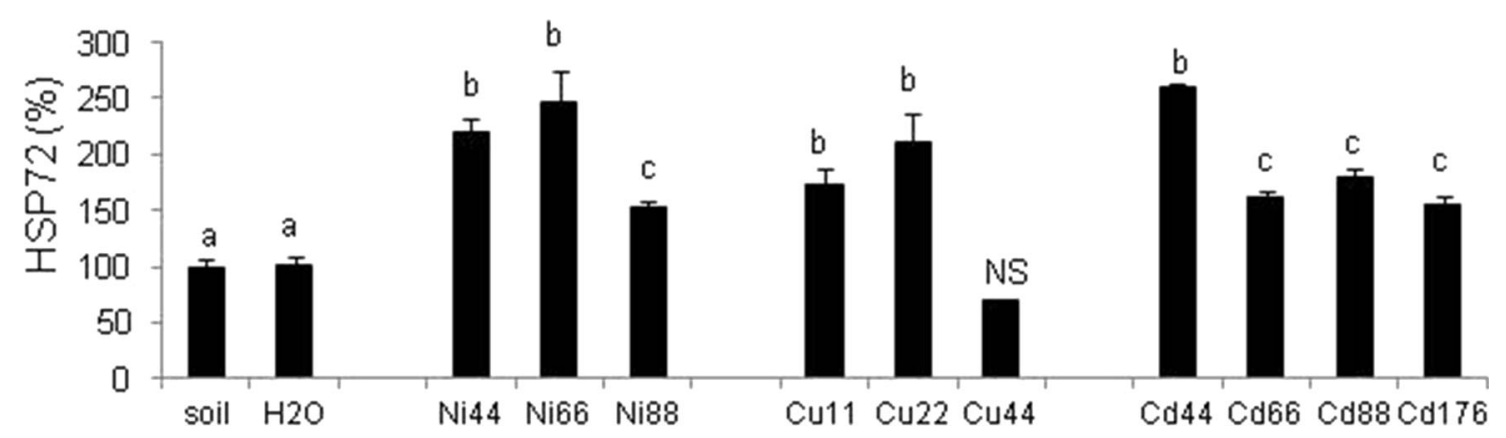

Fig. 5 Dot-blotting detection of stress proteins HSP72 in coelomocyte lysates from Allolobophora chlorotica. Expression of HSP72 was performed with lysates of cells obtained from animals maintained in soil or exposed for 3 days to filters soaked either with water $\left(\mathrm{H}_{2} \mathrm{O}\right)$ or heavy metals, $\mathrm{Ni}, \mathrm{Cu}$, and $\mathrm{Cd}$, in concentration of $11-176 \mu \mathrm{g} / \mathrm{ml}$.

might reflect the differences in exposure conditions or indeed pinpoint species-specific differences in metal handing/distribution. Further experiments would be needed to explore this notion in more detail.

In summary, the exposure of A. chlorotica to metals induces strong phenotypic responses (mortality and changes of body morphology) in the order $\mathrm{Cd}<\mathrm{Ni} \leq \mathrm{Cu}$; however, the sensitivity towards metals in terms of the expression of key stress proteins/metalloproteins (HSP72 and MT-2) is reversed to $\mathrm{Cd}>\mathrm{Ni} \geq \mathrm{Cu}$. However, the degree of induced changes differed between the metals; $\mathrm{Ni}$ and $\mathrm{Cu}$ induced highest mortality and most profound morphological changes, and $\mathrm{Cd}$ exposure led to the strongest expression of cytoprotective proteins. LC50 concentrations of the tested heavy metals were consequently lowest for $\mathrm{Cd}$ and only high doses of $\mathrm{Ni}$ and $\mathrm{Cu}$ killed half of the tested earthworms. These rather unexpected results might be explained by a fact that cadmium is the most poisoning of the tested metals, but in contrast to $\mathrm{Ni}$ (present endogenously in unpolluted animals) and $\mathrm{Cu}$ (e.g., involved in haemoglobin production), it is not essential for any known biological process. Therefore, $\mathrm{Cd}$ triggers much stronger immunobiological response of $A$. chlorotica than $\mathrm{Ni}$ or $\mathrm{Cu}$, which might be naturally present not only in soil but also in the earthworm body. Overall, our study reveals that endogeic earthworms represent an interesting model of ecotoxicological studies and shows that A. chlorotica is better adopted to protect itself against toxic elements that are not essential for its existence.

Acknowledgments The present study was supported by K/ZDS/ 004831. The authors thank Prof Andrew John Morgan (Cardiff School of Biosciences, Cardiff University, Cardiff Wales, UK) for valuable comments and the Department of Cell Biology and Imaging, Institute of Zoology, Jagiellonian University for access to a cryostat. They also thank Ms. Ewa Szczesny for assistance with dot blots and Aleksandra Zolkiewicz with morphological studies.
Densitometric analysis of protein dots. Mean \pm SE, $n=3-10$, $p<0.05$. Different letters ( $a$ vs. $b$ ) indicate that mean values are statistically significantly different from controls. NS no statistical analysis performed due to high mortality

Open Access This article is distributed under the terms of the Creative Commons Attribution 4.0 International License (http://creative commons.org/licenses/by/4.0/), which permits unrestricted use, distribution, and reproduction in any medium, provided you give appropriate credit to the original author(s) and the source, provide a link to the Creative Commons license, and indicate if changes were made.

\section{References}

Asensio V, Kille P, Morgan AJ, Soto M, Marigomez I (2007) Metallothionein expression and neutral red uptake as biomarkers of metal exposure and effect in Eisenia fetida and Lumbricus terrestris exposed to Cd. Eur J Soil Biol 43:233-238

Baumann O (1997) Biogenesis of surface domains in fly photoreceptor cells: fine-structural analysis of the plasma membrane and immunolocalization of $\mathrm{Na}^{+}, \mathrm{K}^{+}$ATPase and $\alpha$-spectrin during cell differentiation. J Comp Neurol 382:429-442

Calisi A, Lionetto MG, Schettino T (2009) Pollutant-induced alterations of granulocyte morphology in the earthworm Eisenia foetida. Ecotoxicol Environ Saf 72:1369-1377

Calisi A, Lionetto MG, De Lorenzis E, Leomanni A, Schettino T (2014) Metallothionein induction in the coelomic fluid of the earthworm Lumbricus terrestris following heavy metal exposure: a short report. Biomed Res Int. doi:10.1155/2014/109386

Chakra Reddy N, Venkateswara Rao J (2008) Biological response of earthworm, Eisenia foetida (Savigny) to an organophosphorous pesticide, profenolos. Ecotoxicol Environ Saf 71:574-582

Cooper EL, Stein EA (1981) Oligochaetes. In: Ratcliffe NA, Rowley AF (eds) Invertebrate blood cells. Academic Press, London, pp $75-140$

Cossarizza A, Cooper EL, Suzuki MW, Salvioli S, Capri M, Gri G, Quaglino D, Franceschi C (1996) Earthworm leukocytes that are not phagocytic and cross-react with several human epitopes can kill human tumor cell lines. Exp Cell Res 224:174-182

Dallinger R (1996) Metallothionein research in terrestrial invertebrates: synopsis and perspectives. Comp Biochem Physiol C 113:125-133

Engelmann P, Kiss J, Csöngei V, Cooper EL, Németh P (2004) Earthworm leukocytes kill HeLa, HEp-2, PC-12 and PA317 cells in vitro. J Biochem Biophys Methods 61:215-227

Farombi EO, Adelowo OA, Ajimoko YR (2007) Biomarkers of oxidative stress and heavy metal levels as indicators of environmental pollution in African catfish (Clarias gariepinus) 
from Nigeria Ogun River. Int $\mathbf{J}$ Environ Res Public Health 4:158-165

Field SG, Kurtz J, Cooper EL, Michiels NK (2004) Evaluation of an innate immune reaction to parasites in the earthworms. J Invertebr Pathol 86:45-49

Fisher E, Molnár L (1992) Environmental aspects of the chloragogenous tissue of earthworms. Soil Biol Biochem 24:1723-1727

Fourie F, Reinecke SA, Reinecke AJ (2007) The determination of earthworm species sensitivity differences to cadmium genotoxicity using the comet assay. Ecotoxicol Environ Saf 67:361-368

Fugère N, Brousseau P, Krzystyniak K, Coderre D, Fournier M (1996) Heavy metal-specific inhibition of phagocytosis and different in vitro sensitivity of heterogeneous coelomocytes from Lumbricus terrestris (Oligochaeta). Toxicology 109:157-166

Giska I, van Gestel CA, Skip B, Laskowski R (2014) Toxicokinetics of metals in the earthworm Lumbricus rubellus exposed to natural polluted soils: relevance of laboratory tests to the field situation. Environ Pollut 190:123-132

Gupta SC, Sharma A, Mishra M, Mishra RK, Chowdhuri DK (2010) Heat shock proteins in toxicology: how close and how far? Life Sci 86:377-384

Hashemi S, Kunwar PS, Blust R, De Boeck G (2008) Differential metallothionein induction patterns in fed and starved carp (Cyprinus carpio) during waterborne copper exposure. Environ Toxicol Chem 10:2154-2158

Hoeckner M, Dallinger R, Stürzenbaum SR (2015) Metallothionein gene activation in the earthworm (Lumbricus rubellus). Biochem Biophys Res Commun 460:537-542

Homa J, Niklińska M, Plytycz B (2003) Effect of heavy metals on coelomocytes of earthworm Allolobophora chlorotica. Pedobiol 47:640-645

Homa J, Olchawa E, Stürzenbaum SR, Morgan AJ, Plytycz B (2005) Early phase immunodetection of metallothionein and heath shock proteins in extruded earthworm coelomocytes after dermal exposure to metal ions. Environ Pollut 135:275-280

Homa J, Stürzenbaum SR, Morgan AJ, Plytycz B (2007) Disrupted homeostasis in coelomocytes of Eisenia fetida and $\mathrm{Al}$ lolobophora chlorotica exposed dermally to heavy metals. Eur J Soil Biol 43:273-280

Homa J, Klimek M, Kruk J, Cocquerelle C, Vandenbulcke F, Plytycz B (2010) Metal-specific effects on metallothionein gene induction and riboflavin content in coelomocytes of Allolobophora chlorotica. Ecotoxicol Environ Saf 73:1937-1943

Honeycutt ME, Roberts BL, Roane DS (1995) Cadmium disposition in the earthworm Eisenia fetida. Ecotoxicol Environ Saf 30:143-150

Kalaç Y, Kimiran A, Ulakoğlu G, Çotuk A (2002) The role of opsonin in phagocytosis by coelomocytes of the earthworm Dendrobaena venata. J Cell Mol Biol 1:7-14

Kammenga JE, Dallinger R, Donker MH, Köhler HR, Simonsen V, Triebskorn R, Weeks JM (2000) Biomarkers in terrestrial invertebrates for ecotoxicological soil risk assessment. Rev Environ Contam Toxicol 164:93-147

Kiang JG, Tsokos GC (1998) Heat shock protein 70 kDa: molecular biology, biochemistry, and physiology. Pharmacol Ther 80:183-201

Kooch Y, Jalilvand H (2008) Earthworms as ecosystem engineers and the most important detritivors in forest soils. Pak J Biol Sci 11:819-825

Kurek A, Homa J, Kauschke E, Plytycz B (2007) Characteristics of coelomocytes of the stubby earthworm, Allolobophora chlorotica (Sav.). Eur J Soil Biol 43:121-126

Leitão S, Moreira-Santos M, Van den Brink PJ, Ribeiro R, José Cerejeira M, Sousa JP (2014) Ethoprophos fate on soil-water interface and effects on non-target terrestrial and aquatic biota under Mediterranean crop-based scenarios. Ecotoxicol Environ Saf 103:36-44

Liess M (2002) Population response to toxicants is altered by intraspecific interaction. Environ Toxicol Chem 21:138-142

Luan W, Li F, Zhang J, Wen R, Li Y, Xiang J (2010) Identification of a novel inducible cytosolic Hsp70 gene in Chinese shrimp Fenneropenaeus chinensis and comparison of its expression with the cognate Hsc70 under different stresses. Cell Stress Chaperones 15:83-93

Maboeta MS, Reinecke SA, Reinecke AJ (2004) The relationship between lysosomal biomarker and organismal responses in an acute toxicity test with Eisenia fetida (Oligochaeta) exposed to the fungicide copper oxychloride. Environ Res 96:95-101

Morgan AJ, Stürzenbaum SR, Winters C, Grime GW, Aziz NA, Kille P (2004) Differential metallothionein expression in earthworm (Lumbricus rubellus) tissues. Ecotoxicol Environ Saf 57:11-19

Moseley P (2000) Stress proteins and the immune response. Immunopharmacology 48:299-302

Nadeau D, Corneau S, Plante I, Morrow G, Tanguay RM (2001) Evaluation for Hsp70 as a biomarker of effect of pollutants on the earthworm Lumbricus terrestris. Cell Stress Chaperones 6:153-163

OECD (1984) Guidelines for the testing of chemicals no. 207 earthworm acute toxicity tests. Organisation for Economic Cooperation and Development, Paris

Olchawa E, Bzowska M, Stürzenbaum SR, Morgan AJ, Plytycz B (2006) Heavy metals effect the coelomocyte-bacteria balance in earthworms: environmental interactions between abiotic and biotic stressors. Environ Pollut 142:373-381

Palm J, van Schaik NLMB, Schröder B (2013) Modelling distribution patterns of anecic, epigeic and endogeic earthworms at catchment-scale in agro-ecosystems. Pedobiologia 56:23-31

Paoletti MG (1999) The role of earthworms for assessment of sustainability and as bioindicators. Agric Ecosyst Environ 74:137-155

Parcellier A, Gurbuxani S, Schmitt E, Solary E, Garrido C (2003) Heat shock proteins, cellular chaperones that modulate mitochondrial cell death pathways. Biochem Biophys Res Commun 304:505-512

Piano A, Valbonesi P, Fabbri E (2004) Expression of cytoprotective proteins, heat shock protein 70 and metallothioneins, in tissues of Ostrea edulis exposed to heat and heavy metals. Cell Stress Chaperones 9:134-142

Plytycz B, Klimek M, Homa J, Mazur AI, Kruk J, Morgan AJ (2011) Species-specific sensitivity of earthworm coelomocytes to dermal metal $(\mathrm{Cd}, \mathrm{Cu}, \mathrm{Ni}, \mathrm{Pb}, \mathrm{Zn})$ exposures: methodological approach. Pedobiologia 54S:5203-5210

Plytycz B, Klimek M, Homa J, Tylko G, Kolaczkowska E (2007) Flow cytometric measurement of neutral red accumulation in earthworm coelomocytes: novel assay for studies on heavy metal exposure. Eur J Soil Biol 43:116-120

Prentø P (1979) Metals and phosphate in the chloragosomes of Lumbricus terrestris and their possible physiological significance. Cell Tissue Res 196:123-134

Reinecke SA, Reinecke AJ (2004) The comet assay as biomarker of heavy metal genotoxicity in earthworms. Arch Environ Contam Toxicol 46:208-215

Roch P (1979) Protein analysis of earthworm coelomic fluid: polymorphic system of the natural hemolysin of Eisenia fetida andrei. Dev Comp Immunol 3:599-608

Roesijadi G (1996) Metallothionein and its role in toxic metal regulation. Comp Biochem Physiol 113:117-123

Roots BI, Johnston PV (1966) The lipids and pigments of the chloragosomes of the earthworm Lumbricus terrestris L. Comp Biochem Physiol 17:285-288 
Scott-Fordsmand JJ, Weeks JM, Hopkin SP (1998) Toxicity of nickel to the earthworm and the applicability of the Neutral Red Retention Assay. Ecotoxicol 7:291-295

Shackelford RE, Kaufmann WK, Paules RS (1999) Cell cycle control, checkpoint mechanisms, and genotoxic stress. Environ Health Perspect 107:5-24

Sizmur T, Tilston EL, Charnock J, Palumbo-Roe B, Watts MJ, Hodson ME (2011) Impacts of epigeic, anecic and endogeic earthworms on metal and metalloid mobility and availability. J Environ Monit 13:266-273

Sogawa N, Sogawa CA, Fukuoka H, Mukubo Y, Yoneyama T, Okano Y, Furuta H, Onodera K (2003) The changes of hepatic metallothionein synthesis and the hepatic damage induced by starvation in mice. Methods Find Exp Clin Pharmacol 25:601-606

Stürzenbaum SR, Winters C, Galay M, Morgan AJ, Kille P (2001) Metal ion trafficking in earthworms. Identification of a cadmium-specific metallothionein. J Biol Chem 276:34013-34018

Valembois P, Lassègues M, Roch P (1992) Formation of brown bodies in the coelomic cavity of the earthworm Eisenia fetida andrei and attendant changes in shape and adhesive capacity of constitutive cells. Dev Comp Immunol 16:95-101

Valembois P, Seymour J, Lassègues M (1994) Evidence of lipofuscin and melanin in the brown body of the earthworm Eisenia fetida andrei. Cell Tissue Res 227:183-188

Venkateswara Rao J, Kavitha P (2004) Toxicity of azodrin on the morphology and acetylcholinesterase activity of the earthworm Eisenia foetida. Environ Res 96:323-327

Venkateswara Rao J, Surya Pavan Y, Madhavendra SS (2003) Toxic effects of chlorpyrifos on morphology and acetylcholinesterase activity in the earthworm, Eisenia foetida. Ecotoxicol Environ Saf 54:296-301

Weeks JM, Svendsen C (1996) Neutral red retention by lysosomes from earthworm (Lumbricus rubellus) coelomocytes: a simple biomarker of exposure to soil copper. Environ Toxicol Chem 15:1801-1805

Wuana RA, Okieimen FE (2011) Heavy metals in contaminated soils: a review of sources, chemistry, risks and best available strategies for remediation. ISRN Ecol. doi:10.5402/2011/402647 